\title{
Social determinants of health related to stay-at-home order adherence and social distancing attitudes among a diverse Deep South population
}

Jennifer L. Lemacks ${ }^{1,2,3^{*}}$, Tammy Greer ${ }^{1,3,4}$, Sermin Aras ${ }^{1,2,3}$, Laurie Abbott5 ${ }^{5}$ Darlene Willis ${ }^{3}$, June Gipson ${ }^{3,6}$ and Mohamed O. Elasri ${ }^{7}$

\begin{abstract}
Objective: To describe COVID-19 related symptoms and medical care experienced in the first six months of the pandemic as well as stay-at-home order adherence, and attitudes related to COVID-19 risk and social distancing among a diverse sample of adults in the Deep South.

Methods: Survey data were collected from 411 Louisiana and Mississippi residents for three weeks in June 2020 through social media.

Results: Over half (52.5\%) of participants who experienced COVID-19 related symptoms (with $41.5 \%$ experiencing at least one symptom) did not feel the severity of symptoms warranted seeking medical care. $91.6 \%$ of the Deep South adults visited certain places or did activities where visiting or gathering with other people was involved during stay-at-home mandates. Religiosity/spirituality, age, education, number of children in the home, attitudes related to COVID-19 risk of complications and social distancing were related to the greater/lesser likelihood of stayat-home order adherence.
\end{abstract}

Conclusions: Various cultural and contextual factors were related to stay-at-home order adherence. Understanding how social values, life stage, socioeconomic, and geographic factors influence stay-at-home order adherence would lead to more effective policy design to improve population adherence.

Keywords: Social determinants of health, COVID-19, Public health, Rural health

\section{Introduction}

The novel coronavirus disease (COVID-19) has become a public health emergency worldwide after being declared as a pandemic by the World Health Organization in March 2020. The United States (US) is among the most-affected countries and with near six million cases

\footnotetext{
* Correspondence: Jennifer.lemacks@usm.edu

'Mississippi INBRE Telenutrition Center, The University of Southern Mississippi, Hattiesburg, MS, USA

${ }^{2}$ School of Kinesiology and Nutrition, The University of Southern Mississippi,

118 College Drive \#5142, Hattiesburg, MS 39406, USA

Full list of author information is available at the end of the article
}

and 190,000 deaths in the first six months [1]. Deep South states, such as Mississippi and Louisiana, with already existing health and social inequities were expected to bear a disproportionate burden from the pandemic. Early studies reported that African Americans had greater hospitalization rates from COVID-19 in comparison to other races but also pointed out the underlying factors such as chronic disease burden, residence in low-income areas, or occupational exposures that could result in a greater risk of COVID-19 infection $[2,3]$. A recent study reported that higher perceived risk

C C The Author(s). 2021 Open Access This article is licensed under a Creative Commons Attribution 4.0 International License, which permits use, sharing, adaptation, distribution and reproduction in any medium or format, as long as you give appropriate credit to the original author(s) and the source, provide a link to the Creative Commons licence, and indicate if changes were made. The images or other third party material in this article are included in the article's Creative Commons licence, unless indicated otherwise in a credit line to the material. If material is not included in the article's Creative Commons licence and your intended use is not permitted by statutory regulation or exceeds the permitted use, you will need to obtain permission directly from the copyright holder. To view a copy of this licence, visit http://creativecommons.org/licenses/by/4.0/ The Creative Commons Public Domain Dedication waiver (http://creativecommons.org/publicdomain/zero/1.0/) applies to the data made available in this article, unless otherwise stated in a credit line to the data. 
for COVID-19 was associated with greater income and younger age [4].

As of September 13, 2020, Mississippi and Louisiana reported a cumulative of 87,805 and 154,955 cases, respectively [5]. Louisiana became an epicenter among southern states as early as April and was the third highest in per capita reported cases in the US [6]. Mississippi had a more steady increase in the number of cases but had the second highest COVID-19 hospitalization rate in the nation by early June [7]. The emergence of COVID-19 cases and scientific and medical uncertainty of disease surveillance urged public health officials and state/local governments to identify and implement interventions to slow the spread of disease [8]. Nonpharmaceutical public health interventions (NPI) such as social distancing and isolation have been shown to be simple and cost-effective ways to control respiratory infections [9]. The Center for Disease Control and Prevention has also identified NPIs as one of the best ways to control pandemic illnesses when vaccines are not yet available [10]. By early April, both Mississippi and Louisiana issued stay-at-home orders and stated guidelines that included mask mandates, restrictions for nonessential businesses, and social distancing to slow the spread of COVID-19. Stay-at-home orders (referred to as "shelter" at home in Louisiana) in both states directed residents to stay at or shelter at home and limit movements outside of their homes beyond essential needs. There is still much too be learned about medical experiences related to the pandemic as well as attitudes and other factors related to stay-at-home order adherence. Additionally, it is critically to understand the factors related to state-at-home order adherence to better inform intervention and policy design. The purpose of this study was to describe COVID-19 related symptoms and medical care experienced in the first six months of the pandemic as well as stay-at-home order adherence, and attitudes related to COVID-19 risk and social distancing among a diverse sample of adults in the Deep South, specifically in the states of Louisiana and Mississippi. Additionally, we determined predictors of stay-at-home order adherence.

\section{Methods}

\section{Study setting and participants}

Adults 18 years of age and older who resided in Mississippi or Louisiana were recruited for the study via social media posts (i.e.., Facebook, Instagram). The posts were shared to various social media pages (i.e., Mississippi INBRE Telenutrition Center and Center for American Indian Research and Studies pages), and promoted by Mississippi INBRE Outreach Scholars and community partners. The data collection period occurred for three weeks in June 2020. The survey was developed to support the research of the MIOS summer research program. The survey was delivered online, lasted approximately 15 to $20 \mathrm{~min}$, and began with an overview of the study and informed consent information. Participants were informed that the purpose of the survey was to conduct a health assessment in Mississippi and Louisiana that include questions related to demographics, standard health information, health views and attitudes, and nutrition, physical activity, and COVID-19 behaviors. Participants were also informed that the information gathered may be utilized for research purposes or by agencies and organizations to develop programs or provide resources to address community needs. Initial questions were presented to determine study eligibility based on age and state of residence. Individuals who did not live in Louisiana or Mississippi or were less than 18 years of age were excluded from participation in the study. After completing the survey, participants were offered the opportunity to accept a \$5 Walmart electronic gift card. All study procedures were reviewed and approved by The University of Southern Mississippi Institutional Review Board.

\section{Measures}

The survey included items related to nutrition, physical activity, COVID-19, and preventable chronic disease. Standard demographics and medical history information included items such as race/ethnicity, gender, educational levels, individual and household income, household size, religion and religiosity/spirituality, chronic disease information for self and family/household members. The study adopted/adapted items from Centers for Disease Control and Prevention COVID-19 Community Survey [11] to collect detailed information regarding COVID-19 related symptoms, medical care sought for COVID-19 related symptoms, COVID-19 related attitudes and social distancing/stay-at-home adherence behaviors. To assess COVID-19 related attitudes, participants selected their agreement on a 7-point Likert scale with the following six statements: 1. I have a greater risk of COVID-19; 2. I live in a neighborhood where it is difficult to socially distance myself from others; 3 . It is easy for me to socially distance from family members in my home; 4 . It is more important to be with my family than to socially distance from them; and 5. It will help decrease the spread of COVID-19 fi I stay away from other people, including my family. Social distancing/stay-at-home order adherence behaviors were yes/no responses for having done any of the following behaviors during the stay-at-home order time period (April 2020): 1. Gone out to a restaurant, bar, club, or other place where people gather; 2 . Visit with friends, relatives, or neighbors aged 60 years or older; 3: Gone to the grocery store or pharmacy; 4: Gone to a friend, 
neighbor, or relative's house (other than your own); 5. Had more than 10 friends, neighbors, or relatives over for a gathering or meal; 6. Gone to a family gathering with more than 10 people; 7 . Gone to a gathering of friends with more than 10 people; and 8: Gone to a faith-based gathering. The question stem was "During the month of April 2020, have you ..." and participants were asked to "select all that apply." Other items collected and not included in this study were fatalistic attitudes related to preventable chronic disease, dietary and physical activity behaviors, peer social support for diet and physical activity, and community health values related to preventable chronic diseases.

\section{Statistical analysis}

Descriptive and frequency data were computed for all variables and all analyses were conducted using IBM SPSS Statistics 27.0 software. To determine whether COVID-19 -related attitudes predicted social distancing/ stay-at-home adherence behaviors net of the effects of demographic and psychosocial variables, we proceeded through a series of steps to determine which variables to include in the final model. First, simple correlations among demographic variables (age, education, income, the number of adults and the number of children in the household) and psychosocial variables (religiosity/spirituality, perceptions of physical health and perceptions of social-emotional support) were computed. Eight hierarchical binary logistic regression models were used to test the contributions of demographic, psychosocial and COVID-19 -related attitude variables on each of the social distance/stay-at-home order adherence variables.

\section{Results}

\section{Demographics, impact of COVID-19 on employment and} medical history

411 participants attempted survey completion. Of the 411 participants, $99 \%$ of participants completed all of the demographic information, $97 \%$ reported on whether they had been diagnosed with a chronic disease, 97\% reported on whether or not they experienced COVID-19 symptoms, 91\% reported on social support, and $90 \%$ reported on COVID-19 related attitudes and behaviors. The decrease in responses followed the order of questions in the survey with questions asked early in the survey having higher response rates compared to those answered later in the survey. Those who completed the survey $(n=368)$, were on average older (mean, $M=$ 33.93, standard deviation, $\mathrm{S}=14.03)$ compared to those who did not complete the survey $(M=28.60, S=12.30$; $F$ $(1,409)=5.69, p=.02)$, more educated $(\mathrm{r}=.16, p<.01)$, and more likely to be married (41\%) compared to noncompleters (17\%; Chi Square [4] = 13.02, $p=0.01$ ), but not different with regard to race, employment status, or income. Demographics for the 368 participants who completed the survey are located in Table 1.

The final surveyed sample of Deep South residents ( $n=368$ ) was relatively young with $78.1 \%$ of respondents 45 years or younger and an age range of 18 to 79 years. Most respondents were female $(75.0 \%)$, married $(41.0 \%)$ or single $(46.5 \%)$, had at least some college $(83.1 \%)$, reported an individual annual income of $\$ 59,999$ or less (86.1\%), and about half reported employment in a fulltime position (46.5\%). About half reported zero children (54.3\%) followed by one to two children (38.5\%) living in the home, and one to three adults living in the household (84.3\%). Most respondents were Baptist (36.1\%) followed by non-denominational (16.8\%) and Catholic (16.0\%). Most participants $(75.8 \%)$ reported that they were fairly or very religious. Table 1 provides detailed information for demographic data.

$29.7 \%(n=104)$ of participants reported that the COVID-19 pandemic caused them to work remotely or from home more than usual. $14.6 \%(n=51), 18.3 \%(n=$ $64)$ and $17.7 \%(n=62)$ either worked more hours than usual, worked fewer hours than usual or were not able to work, respectively. Only $5.1 \%(n=18)$ had difficulty arranging childcare and $0.9 \%(n=3)$ had incurred increased childcare costs. $14.3 \%(n=50)$ experienced reduced income/pay and $8.3 \%(n=29)$ were not paid at all.

\section{COVID-19 related symptoms and medical care}

214 (58.2\%) of the 368 participants reported not experiencing any of the five COVID-19 related symptoms between January and July 2020. Of those who reported at least one symptom $(n=154)$, the most reported symptom was a runny/stuffy nose followed by sore throat and cough. Nearly half $(46.8 \%)$ of those who experienced at least one symptom went to a healthcare professional for the COVID-19 related symptom(s). Less than a quarter (18.1\%) of those individuals who sought medical care for a COVID-19 related symptom were tested for COVID19 and $48.6 \%$ were tested for influenza. The most common healthcare setting visited was a doctor's office (41.7\%) followed by the urgent care center (38.9\%). Most individuals who did not seek medical care for COVID19 related symptoms $(n=82)$ reported they did not do so because the symptoms were not considered severe enough to seek medical care $(79.3 \%)$. Those who selected the "other" response indicated the following reasons for not seeking medical care: had sinus/allergy issues, avoided missing work/school, or self-medicated (data not shown). Table 2 provides complete information for quantitative data.

\section{COVID-19 related behaviors and attitudes}

During the month of April 2020, which is the time period when both states of Mississippi and Louisiana 
Table 1 Demographic descriptive data for the Deep South sample $(n=368)$

Demographics

Age

Categorical Demographics

Race/Ethnicity

State of Residence

Gender

Education

Individual Annual Income

Household Annual Income

Children in Household

Adults in Household

Marital Status
Years

Category Labels

White

Black or African American

American Indian or Alaskan Native

Hispanic/Latino

Asian

Two or more races

Louisiana

Mississippi

Male

Female

Less than a high school degree

A high school degree

Some college, but not a college degree

A 2-year or vocational degree

A 4-year college degree or higher

$\$ 0$ to $\$ 19,999$

$\$ 20,000$ to $\$ 29,999$

$\$ 30,000$ to $\$ 39,999$

$\$ 40,000$ to $\$ 49,999$

$\$ 50,000$ to $\$ 59,999$

$\$ 60,000$ or greater

$\$ 0$ to $\$ 19,999$

$\$ 20,000$ to $\$ 29,999$

$\$ 30,000$ to $\$ 39,999$

$\$ 40,000$ to $\$ 49,999$

$\$ 50,000$ to $\$ 59,999$

$\$ 60,000$ or greater

0

1

2

4

5 or more

0

2

4

5 or more

Single

Married

Cohabitating
Mean (SD)

33.93 (14.03)

$\%$ (n)

43.5 (160)

30.7 (113)

$17.9(66)$

$1.4(5)$

1.1 (4)

$5.4(20)$

35.3 (130)

64.7 (238)

25.0 (92)

75.0 (276)

3.8 (14)

13.0 (48)

25.5 (94)

16.0 (59)

41.6 (153)

41.6 (153)

12.5 (46)

14.1 (52)

$9.2(34)$

8.7 (32)

11.9 (51)

14.1 (52)

$7.9(29)$

11.1 (41)

$8.2(30)$

6.3 (23)

52.4 (193)

54.3 (200)

23.6 (87)

14.9 (55)

4.1 (15)

1.9 (7)

1.1 (4)

$2.7(10)$

17.7 (65)

47.3 (174)

$19.3(71)$

10.1 (37)

3.0 (11)

46.5 (171)

41.0 (151)

$8.4(31)$ 
Table 1 Demographic descriptive data for the Deep South sample $(n=368)$ (Continued)

\begin{tabular}{|c|c|c|}
\hline \multicolumn{2}{|l|}{ Demographics } & \multirow{2}{*}{$\begin{array}{l}\text { Mean (SD) } \\
4.1(15)\end{array}$} \\
\hline & Divorced/Separated & \\
\hline \multirow[t]{9}{*}{ Employment Status } & I do not work but I stay at home to care for children or elderly family members & $4.6(17)$ \\
\hline & I do not work because I am retired & $2.4(8)$ \\
\hline & I have a full-time position & $46.5(171)$ \\
\hline & I have a part-time position & $7.9(29)$ \\
\hline & I have more than one part time position & $4.3(16)$ \\
\hline & I am a student and work part or full time & $17.1(63)$ \\
\hline & I am a student and do not work & $7.9(29)$ \\
\hline & I do not work and am not looking for work & $3.5(13)$ \\
\hline & I do not work but I am looking for work & $5.7(21)$ \\
\hline \multirow[t]{5}{*}{ Perceptions of Physical Health } & Poor & $3.3(12)$ \\
\hline & Fair & $59(16.0)$ \\
\hline & Good & $142(38.6)$ \\
\hline & Very Good & $119(32.3)$ \\
\hline & Excellent & $36(9.8)$ \\
\hline \multirow[t]{2}{*}{ Health Insurance Status } & Has health insurance support & $88.9(327)$ \\
\hline & No health insurance of any kind & $11.1(41)$ \\
\hline \multirow[t]{8}{*}{ Religion } & No religious affiliation & $11.4(40)$ \\
\hline & Baptist & $36.1(133)$ \\
\hline & Catholic & $16.0(59)$ \\
\hline & Methodist & $5.2(19)$ \\
\hline & Non-denominational & $16.8(62)$ \\
\hline & Presbyterian & $1.6(6)$ \\
\hline & Other & $8.7(32)$ \\
\hline & Prefer not to respond & $4.6(17)$ \\
\hline \multirow[t]{4}{*}{ Religiosity/Spirituality } & Not religious at all & $6.3(23)$ \\
\hline & Not too religious & $17.9(66)$ \\
\hline & Fairly religious & $45.4(167)$ \\
\hline & Very religious & $30.4(112)$ \\
\hline \multirow[t]{5}{*}{ Social \& Emotional Support } & Never & $2.7(10)$ \\
\hline & Rarely & $11.4(42)$ \\
\hline & Sometimes & $20.7(76)$ \\
\hline & Usually & $41.6(153)$ \\
\hline & Always & $23.6(87)$ \\
\hline
\end{tabular}

were under a stay-at-home order, the majority of respondents $(85.1 \%)$ visited a grocery store/pharmacy followed by visiting a friend, neighbor, or relative's house $(60.1 \%)$, and visited with friends, relatives or neighbors aged 60 years or older $(31.4 \%)$. Only $7.5 \%(n=31)$ of respondents did not visit any of the places or do any of the activities listed. Other social distancing/stay-at-home adherence behaviors are described in Table 3.

$54.9 \%$ of participants somewhat disagreed-tostrongly disagreed that they have a greater risk of
COVID-19 complications. $81.3 \%$ of participants somewhat disagreed-to-strongly disagreed that they live in a neighborhood where it is difficult to socially distance from others. $41.0 \%$ of respondents somewhat agreed-to-strongly agreed that it is more important to be with family than to social distance. $62.5 \%$ of participants somewhat agreed-to-strongly agreed that staying away from other people, including family, would help decrease the spread of COVID-19. A complete distribution of data is reported in Table 4. 
Table 2 COVID-19 related symptoms experiences and medical care sought between January and July $2020(n=368)$

\begin{tabular}{|c|c|}
\hline & $\%(\mathbf{n})$ \\
\hline \multicolumn{2}{|c|}{$\begin{array}{l}\text { Reported COVID-19 related symptoms between January and July } 2020(n= \\
\text { 154) }\end{array}$} \\
\hline Fever & $29.8(46)$ \\
\hline Cough & $59.7(92)$ \\
\hline Sore Throat & $60.4(93)$ \\
\hline Runny or Stuffy Nose & $79.2(122)$ \\
\hline Difficulty breathing & $20.1(31)$ \\
\hline \multicolumn{2}{|c|}{$\begin{array}{l}\text { Experienced at least } 1 \text { COVID19 related symptom and saw healthcare } \\
\text { professional for symptom }(n=72)\end{array}$} \\
\hline Tested for COVID-19 at healthcare visit & $18.1(13)$ \\
\hline Received positive test result for COVID-19 & $15.4(2)$ \\
\hline Tested for influenza at healthcare visit & $48.6(35)$ \\
\hline Received positive test result for influenza & $8.6(3)$ \\
\hline \multicolumn{2}{|c|}{ Location of healthcare visit for COVID-19 related symptom $(n=72)$} \\
\hline Doctor's office & $41.7(30)$ \\
\hline Urgent care center & $38.9(28)$ \\
\hline Telemedicine/telephone triage & $8.3(6)$ \\
\hline Emergency room at a hospital & $6.9(5)$ \\
\hline Health department/public health clinic & $2.8(2)$ \\
\hline Somewhere else & $1.4(1)$ \\
\hline \multicolumn{2}{|c|}{$\begin{array}{l}\text { Reasons for not seeking medical care for COVID-19 related symptom ( } n= \\
\text { 82) }\end{array}$} \\
\hline Did not feel bad enough & $79.3(65)$ \\
\hline Distrust healthcare system & $8.5(7)$ \\
\hline Did not have insurance & $13.4(11)$ \\
\hline Worried about cost & $11.0(9)$ \\
\hline Did not want to spend money & $15.9(13)$ \\
\hline Did not have paid sick leave & $9.8(8)$ \\
\hline No one to look after my family & $2.4(2)$ \\
\hline Other & $17.1(14)$ \\
\hline
\end{tabular}

Table 3 Most to least common social behaviors during stay-athome order (April 2020, $n=337$ )

\begin{tabular}{|c|c|}
\hline & $\%(n)$ \\
\hline Gone to the grocery store or pharmacy & $85.1(313)$ \\
\hline $\begin{array}{l}\text { Gone to a friend, neighbor, or relative's house } \\
\text { (other than your own) }\end{array}$ & $60.1(221)$ \\
\hline $\begin{array}{l}\text { Visited with friends, relatives, or neighbors aged } \\
60 \text { years or older }\end{array}$ & $31.4(129)$ \\
\hline $\begin{array}{l}\text { Gone out to a restaurant, bar, club, or other } \\
\text { place where people gather }\end{array}$ & $21.7(80)$ \\
\hline $\begin{array}{l}\text { Gone to a family gathering with more than } \\
10 \text { people }\end{array}$ & $14.1(82)$ \\
\hline Gone to a faith-based gathering & $10.3(38)$ \\
\hline $\begin{array}{l}\text { Had more than } 10 \text { friends, neighbors, or relatives } \\
\text { over for a gathering or meal }\end{array}$ & $8.7(32)$ \\
\hline $\begin{array}{l}\text { Gone to a gathering of friends with more than } \\
10 \text { people }\end{array}$ & $8.8(38)$ \\
\hline
\end{tabular}

\section{Correlation and regression analyses}

Power analysis indicated that a sample size of 300 was needed to detect between a small and medium effect size (f $[2]=.10$, power $=.99$, alpha $=.05$ ) to test for the relation between COVID-19 behaviors and the five COVID19 attitudes over and above the explanatory power of demographic variables [5] and psychosocial variables [3]. Simple correlations among demographic and psychosocial variables revealed, at most, moderate correlations between predictor variables (See Table 5). Moderate correlations were also noted among attitudes related to COVID-19 risk and social distancing and social behaviors related to stay-at-home order adherence (See Table 6). Findings indicated that the older the participants and greater agreement that "it will help decrease the spread of COVID-19 if I stay away from other people, including my family," the less likely participants were to report going to a restaurant, bar, club, or other place where people gather. The younger and more educated the participants, and the greater the agreement with "It is more important to be with my family than to socially distance from them," the more likely to report having gone to a friend, neighbor, or relative's home. The greater the importance to be with family than to socially distance from them, the more likely they were to report attending family gatherings of 10 or more people. The greater the agreement that they lived in a neighborhood where it is difficult to social distance, the more likely they were to have gone to a gather of friends with more than 10 people. The more religious the participants, the more likely they were to report having gone to a gathering with friends with more than 10 people or attended a faith-based gathering. Table 7 contains complete regression analyses results.

\section{Discussion}

This study identified COVID-19 related symptoms and medical care during the first six months of the pandemic, and described attitudes, demographic and psychosocial factors that were related to social distancing/stay-at-home adherence behaviors during statewide stay-at-home mandates. Our findings indicated that near half of participants who experienced COVID-19 related symptoms between January and July 2020 sought medical care at predominantly doctor's offices and urgent care centers. Most of the other half did not seek medical care for symptoms because they did not feel symptoms were severe enough for medical care. Approximately two-thirds of participants reported that they disagreed that they were at greater risk of COVID-19 complications and agreed that staying away from other people would decrease the spread of COVID-19. An overwhelming majority reported that they lived in a neighborhood where it was not difficult to social distance from others. Several factors, including demographics, 
Table 4 Likert scale distribution of attitudes related to COVID-19 risk and social distancing, $n=368$

\begin{tabular}{|c|c|c|c|c|c|c|c|}
\hline & $\begin{array}{l}\text { Strongly } \\
\text { Disagree }\end{array}$ & Disagree & $\begin{array}{l}\text { Somewhat } \\
\text { Disagree }\end{array}$ & $\begin{array}{l}\text { Neither Agree } \\
\text { nor Disagree }\end{array}$ & $\begin{array}{l}\text { Somewhat } \\
\text { Agree }\end{array}$ & Agree & $\begin{array}{l}\text { Strongly } \\
\text { Agree }\end{array}$ \\
\hline Attitude Statements & $\%(n)$ & & & & & & \\
\hline I have a greater risk of COVID-19 complications. & $28.0(103)$ & $26.9(99)$ & $5.4(20)$ & $13.9(51)$ & $10.9(40)$ & $\begin{array}{l}8.4 \\
(31)\end{array}$ & $6.5(24)$ \\
\hline $\begin{array}{l}\text { I live in a neighborhood where it is difficult to socially } \\
\text { distance myself from others. }\end{array}$ & $43.8(161)$ & $\begin{array}{l}37.5 \\
(138)\end{array}$ & $4.3(16)$ & $7.6(28)$ & $3.0(11)$ & $2.4(9)$ & $1.4(5)$ \\
\hline $\begin{array}{l}\text { It is easy for me to socially distance from family members } \\
\text { in my home. }\end{array}$ & $17.9(66)$ & $16.0(59)$ & $7.6(28)$ & $8.7(32)$ & $11.4(42)$ & $\begin{array}{l}25.3 \\
(93)\end{array}$ & $13.0(48)$ \\
\hline $\begin{array}{l}\text { It is more important to be with my family than to socially } \\
\text { distance from them. }\end{array}$ & $9.2(34)$ & $15.8(58)$ & $8.2(30)$ & $25.8(95)$ & $14.9(55)$ & $\begin{array}{l}15.8 \\
(58)\end{array}$ & $10.3(38)$ \\
\hline $\begin{array}{l}\text { It will help decrease the spread of COVID-19 if I stay away } \\
\text { from other people including my family. }\end{array}$ & $5.7(21)$ & $7.3(27)$ & $7.9(29)$ & $16.6(61)$ & $19.3(71)$ & $\begin{array}{l}26.6 \\
(98)\end{array}$ & $16.6(61)$ \\
\hline
\end{tabular}

psychosocial and COVID-19 attitudes, were related to a greater/lessor likelihood of stay-at-home order adherence.

NPIs such as stay-at-home orders have been shown to reduce the spread of disease, including reduced rates of COVID-19 cases [12]. A current longitudinal study found that individuals living in highly populated areas made less frequent essential trips to places like the grocery store or pharmacy and were more likely to adhere to social distancing guidelines [13]. Louisiana and Mississippi are largely rural states, and most participants did visit a grocery store/pharmacy during the stay-at-home order period. It should be noted that our sample was composed of a greater proportion of women, who could be caretakers of their home and responsible for the food and other household necessities. Another study in Bangladesh women was similar where $89.1 \%$ of 2424 respondents reported leaving the house for "shopping necessities" during the over two-month stay-at-home order [14]. Additionally, near half of our sample reported changes to employment that would worsen socioeconomic conditions. While stay-at-home orders may reduce or slow disease incidence, economical and psychological impacts have also been reported at individual and community levels among other populations $[14,15]$. This is important to consider, especially in the Deep South, where underserved populations already experience disparities in many areas, which could be exacerbated by stay-at-home orders.

Most participants reported as fairly/very religious/spiritual and some type of religious affiliation. This region of the country is among the highest for church attendance compared to other states and regions of the US [16]. Other research has shown that attending places of worship within two weeks prior to testing positive for COVID-19 had higher likelihood of testing positive for COVID-19 [17]. Our research shows that religiosity/spirituality did increase the likelihood of having attended a faith-based gathering during the stay-at-home order. This could be a unique contributor to the spread of COVID-19 in this region.

Attitudes about staying away from other people to prevent COVID-19 and the importance of family over social distancing along with age, was associated with the likelihood of going where other people gather (restaurants/

Table 5 Correlations Among Demographic Predictor Variables $(n=368$ )

\begin{tabular}{|c|c|c|c|c|c|c|c|c|}
\hline $\begin{array}{l}\text { Variable } \\
\text { [Mean (Standard } \\
\text { Deviation), Range] }\end{array}$ & $\begin{array}{l}\text { Age } \\
{[33.9(14.0),} \\
18-79]\end{array}$ & $\begin{array}{l}\text { Education } \\
{[3.8(1.2),} \\
1-5]\end{array}$ & $\begin{array}{l}\text { Income } \\
{[4.0(2.5),} \\
2-12]\end{array}$ & $\begin{array}{l}\text { Household } \\
\text { Adults } \\
{[2.3(1.0),} \\
1-6] \\
\end{array}$ & $\begin{array}{l}\text { Household } \\
\text { Children } \\
{[0.8(1.1), 0-} \\
6]\end{array}$ & $\begin{array}{l}\text { Perceptions } \\
\text { of Health } \\
{[3.3(1.0), 1-5]}\end{array}$ & $\begin{array}{l}\text { Social \& } \\
\text { Emotional } \\
\text { Support } \\
{[3.7(1.0), 1-5]}\end{array}$ & $\begin{array}{l}\text { Spirituality } \\
{[3.0(0.9),} \\
1-4]\end{array}$ \\
\hline Age & - & .05 & $.54^{* *}$ & $-.15^{* *}$ & -.08 & -.05 & $.14^{* *}$ & $.17^{* *}$ \\
\hline Education & & & $.29^{* *}$ & .02 & $-.11^{*}$ & $.14^{* *}$ & .07 & .04 \\
\hline Income & & & & $-.19^{* *}$ & -.07 & $.10^{*}$ & $.14^{* *}$ & .04 \\
\hline Household Adults & & & & & $.15^{* *}$ & $.14^{* *}$ & .03 & .01 \\
\hline Household Children & & & & & & -.01 & .001 & $-.13^{*}$ \\
\hline Perceptions of Health & & & & & & & $.29 * *$ & $.17^{* *}$ \\
\hline $\begin{array}{l}\text { Social \& Emotional } \\
\text { Support }\end{array}$ & & & & & & & & $.18^{* *}$ \\
\hline
\end{tabular}

${ }^{*} p \leq .05,{ }^{* *} \mathrm{p} \leq .01$ 
Table 6 Correlations among Attitudes related to COVID-19 Risk and Social Distancing and Social Behaviors Related to Stay-at-Home Order Adherence

\begin{tabular}{|c|c|c|c|c|c|c|c|c|}
\hline & $\begin{array}{l}\text { Gone out to a } \\
\text { restaurant, bar, } \\
\text { club, or other } \\
\text { place where } \\
\text { people gather }\end{array}$ & $\begin{array}{l}\text { Visited with } \\
\text { friends, } \\
\text { relatives, or } \\
\text { neighbors } \\
\text { aged } 60 \text { years } \\
\text { or older }\end{array}$ & $\begin{array}{l}\text { Gone to } \\
\text { the } \\
\text { grocery } \\
\text { store or } \\
\text { pharmacy }\end{array}$ & $\begin{array}{l}\text { Gone to a } \\
\text { friend, } \\
\text { neighbor, or } \\
\text { relative's } \\
\text { house (other } \\
\text { than your } \\
\text { own) }\end{array}$ & $\begin{array}{l}\text { Had more than } \\
10 \text { friends, } \\
\text { neighbors, or } \\
\text { relatives over } \\
\text { for a gathering } \\
\text { or meal }\end{array}$ & 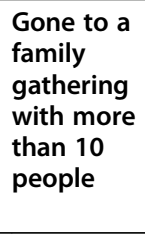 & $\begin{array}{l}\text { Gone to a } \\
\text { gathering } \\
\text { of friends } \\
\text { with more } \\
\text { than } 10 \\
\text { people }\end{array}$ & $\begin{array}{l}\text { Gone to } \\
\text { a faith- } \\
\text { based } \\
\text { gathering }\end{array}$ \\
\hline $\begin{array}{l}\text { I have a greater risk } \\
\text { of COVID-19 } \\
\text { complications. }\end{array}$ & $-0.15^{* *}$ & -0.059 & -0.078 & $-.117^{*}$ & -0.067 & -0.021 & -0.016 & -0.041 \\
\hline $\begin{array}{l}\text { I live in a } \\
\text { neighborhood } \\
\text { where it is difficult } \\
\text { to socially distance } \\
\text { myself from others. }\end{array}$ & 0.024 & -0.033 & -0.019 & 0.046 & 0.097 & 0.066 & 0.055 & -0.032 \\
\hline $\begin{array}{l}\text { It is easy for me to } \\
\text { socially distance } \\
\text { from family } \\
\text { members in my } \\
\text { home. }\end{array}$ & $-.147^{* *}$ & -0.068 & -0.038 & $-.116^{*}$ & $-.132^{*}$ & $-.109^{*}$ & -0.087 & 0.079 \\
\hline $\begin{array}{l}\text { It is more important } \\
\text { to be with my family } \\
\text { than to socially } \\
\text { distance from them. }\end{array}$ & 0.084 & $.111^{*}$ & 0.040 & $.119^{*}$ & $.125^{*}$ & $.159^{* *}$ & 0.090 & 0.052 \\
\hline $\begin{array}{l}\text { It will help decrease } \\
\text { the spread of } \\
\text { COVID-19 if I stay } \\
\text { away from other } \\
\text { people including my } \\
\text { family. }\end{array}$ & $-.184^{* *}$ & -0.042 & -0.025 & -0.070 & $-.122^{*}$ & $-.168^{* *}$ & $-.115^{*}$ & $-.120^{*}$ \\
\hline
\end{tabular}

bars/clubs) and to faith-based gatherings. Younger adults and disagreement with staying away from other people would help decrease the spread of COVID-19 were more likely to have gone to gathering places; younger adults were also more likely to have gone to a gathering of friends with more than 10 people. Research has reported that COVID-19 transmission was highest in younger adults later on in the pandemic (June to August) compared to earlier on (January to May) [18]. Additionally, a very large study of over 30,000 people in the UK (the CORSAIR study) found that non-adherence to selfisolation behaviors was associated with younger age groups [19]. This could be attributed to public health messages that older/elderly adults were at a greater risk of COVID-19 complications compared to younger populations.

Those who placed greater value on being with family than social distancing were more likely to go to a family gathering of more than 10 people and to a friend, neighbor, or relative's house. Prior research has shown that individuals who tested positive for COVID-19 reported significantly more close contacts with a person with known COVID-19 within the two weeks prior to being tested compared to those who tested negative for
COVID-19 [20]. Of those that had a close contact with an individual who tested positive for COVID-19, "family" was the most commonly reported relationship of the close contact with COVID-19, accounting for about 50\% of the responses, followed by "work colleague" and "friend." [20]

The reported results highlight unique cultural and contextual factors that may influence stay-at-home order adherence and possibly other NPIs. During a similar time period, the first two weeks of May 2020, 77.4, 83.0 and $84.6 \%$ of a US, Los Angeles, and New York City sample, respectively, reported no contact with anyone outside of their home as a COVID-19 mitigation strategy [21]. Similarly, 75.1 to $77.6 \%$ of those samples reported always avoiding groups of 10 or more people [21]. This is starkly different from our results where only $7.5 \%$ of our sample did not visit any of the places or do any of the listed activities where visiting or gathering with other people was involved. As mentioned earlier, there may be geographic attributions to stay-at-home order adherence, in addition to socioeconomic and cultural considerations. However, the CORSAIR study reported that going to the grocery store/pharmacy was one of the reasons for not self-isolating when presented with 
Table 7 Regression Analyses with Demographic, Psychosocial, and Attitudes Predictors of Social Behaviors related to Stay-At-Home Order Adherence

\begin{tabular}{|c|c|c|c|c|c|c|c|c|c|}
\hline & & \multicolumn{8}{|c|}{ Social behaviors related to stay-at-home order adherence } \\
\hline & & $\begin{array}{l}\text { Gone out to } \\
\text { a restaurant, } \\
\text { bar, club, or } \\
\text { other place } \\
\text { where } \\
\text { people } \\
\text { gather }\end{array}$ & $\begin{array}{l}\text { Visited with } \\
\text { friends, } \\
\text { relatives, or } \\
\text { neighbors } \\
\text { aged } 60 \\
\text { years or } \\
\text { older }\end{array}$ & $\begin{array}{l}\text { Gone to } \\
\text { the } \\
\text { grocery } \\
\text { store or } \\
\text { pharmacy }\end{array}$ & $\begin{array}{l}\text { Gone to a } \\
\text { friend, } \\
\text { neighbor, or } \\
\text { relative's } \\
\text { house } \\
\text { (other than } \\
\text { your own) }\end{array}$ & $\begin{array}{l}\text { Had more } \\
\text { than } 10 \\
\text { friends, } \\
\text { neighbors, or } \\
\text { relatives over } \\
\text { for a } \\
\text { gathering or } \\
\text { meal }\end{array}$ & 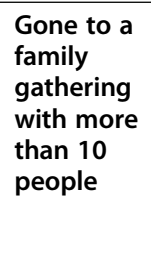 & $\begin{array}{l}\text { Gone to a } \\
\text { gathering } \\
\text { of friends } \\
\text { with more } \\
\text { than } 10 \\
\text { people }\end{array}$ & $\begin{array}{l}\text { Gone to } \\
\text { a faith- } \\
\text { based } \\
\text { gathering }\end{array}$ \\
\hline & & b (odds) & & & & & & & \\
\hline \multirow{7}{*}{$\begin{array}{l}\text { Step } 1 \\
\text { Demographic } \\
\text { Variables }\end{array}$} & Age & $.97^{* *}$ & .99 & 1.01 & $.97^{* *}$ & .98 & 1.00 & .97 & .98 \\
\hline & Education & .84 & 1.1 & 1.12 & $1.26^{* *}$ & .77 & .98 & 1.08 & .81 \\
\hline & Income & .95 & .94 & .93 & 1.00 & .96 & .95 & .95 & .90 \\
\hline & $\begin{array}{l}\text { Household } \\
\text { Adults }\end{array}$ & 1.1 & .96 & 1.12 & .93 & 1.08 & .88 & .77 & .83 \\
\hline & $\begin{array}{l}\text { Household } \\
\text { Children }\end{array}$ & .85 & .93 & .91 & .85 & 1.10 & 1.32 & .91 & 1.11 \\
\hline & Y intercept & 2.0 & .65 & 3.04 & $2.94^{*}$ & .52 & .26 & .46 & .79 \\
\hline & $d f=5$ & $x^{2}=21.3^{* *}$ & $x^{2}=4.6$ & $x^{2}=3.4$ & $x^{2}=28.0^{* *}$ & $x^{2}=9.2$ & $x^{2}=6.5$ & $x^{2}=6.5$ & $x^{2}=8.3$ \\
\hline \multirow{5}{*}{$\begin{array}{l}\text { Step } 2 \\
\text { Psychosocial } \\
\text { Variables }\end{array}$} & Religiosity & 1.02 & 1.30 & .86 & .93 & 1.26 & 1.07 & $1.8^{*}$ & $3.94^{* *}$ \\
\hline & Health & 1.02 & 1.05 & .84 & .99 & .99 & 1.16 & .76 & .95 \\
\hline & Social Support & 1.16 & 1.02 & 1.29 & 1.02 & .91 & .85 & .96 & .73 \\
\hline & $Y$ intercept & 1.16 & .27 & 3.57 & 3.44 & .38 & .23 & .20 & $.04^{*}$ \\
\hline & $\begin{array}{l}d f=3 \\
d f=8\end{array}$ & $\begin{array}{l}x^{2}=1.5 \\
x^{2}=22.8^{* *}\end{array}$ & $\begin{array}{l}x^{2}=4.4 \\
x^{2}=9.0\end{array}$ & $\begin{array}{l}x^{2}=3.8 \\
x^{2}=7.1\end{array}$ & $\begin{array}{l}x^{2}=.4 \\
x^{2}=28.3^{* *}\end{array}$ & $\begin{array}{l}x^{2}=1.3 \\
x^{2}=10.5\end{array}$ & $\begin{array}{l}x^{2}=1.6 \\
x^{2}=8.1\end{array}$ & $\begin{array}{l}x^{2}=6.3 \\
x^{2}=14.2\end{array}$ & $\begin{array}{l}x^{2}=23.4^{* *} \\
x^{2}=28.3^{* *}\end{array}$ \\
\hline \multirow{7}{*}{$\begin{array}{l}\text { Step } 3 \\
\text { Attitudes } \\
\text { related to } \\
\text { COVID-19 } \\
\text { risk and so- } \\
\text { cial } \\
\text { distancing }\end{array}$} & $\begin{array}{l}\text { I have a greater } \\
\text { risk of COVID-19 } \\
\text { complications. }\end{array}$ & .86 & .98 & .86 & .93 & .90 & 1.01 & .88 & 1.02 \\
\hline & $\begin{array}{l}\text { I live in a } \\
\text { neighborhood } \\
\text { where it is } \\
\text { difficult to social } \\
\text { distance myself } \\
\text { from others. }\end{array}$ & 1.06 & .94 & 1.03 & 1.04 & 1.27 & 1.15 & $1.78^{*}$ & .89 \\
\hline & $\begin{array}{l}\text { It is easy for me } \\
\text { to socially } \\
\text { distance from } \\
\text { family members } \\
\text { in my home. }\end{array}$ & .89 & .94 & .98 & .93 & .86 & .94 & .79 & $1.23^{*}$ \\
\hline & $\begin{array}{l}\text { It is more } \\
\text { important to be } \\
\text { with my family } \\
\text { than to socially } \\
\text { distance from } \\
\text { them. }\end{array}$ & 1.04 & 1.12 & 1.04 & $1.17^{*}$ & 1.18 & $1.24^{*}$ & .96 & 1.02 \\
\hline & $\begin{array}{l}\text { It will help } \\
\text { decrease the } \\
\text { spread of } \\
\text { COVID19 if I stay } \\
\text { away from other } \\
\text { people, including } \\
\text { my family. }\end{array}$ & $.80^{* *}$ & 1.00 & .98 & .95 & .89 & .84 & 1.00 & $.74^{*}$ \\
\hline & $Y$ intercept & 7.78 & .36 & 6.83 & 5.21 & .52 & .22 & 1.11 & .07 \\
\hline & $\begin{array}{l}d f=5 \\
d f=13\end{array}$ & $\begin{array}{l}x^{2}=21.3^{* *} \\
x^{2}=44.1^{* *}\end{array}$ & $\begin{array}{l}x^{2}=6.3 \\
x^{2}=15.3\end{array}$ & $\begin{array}{l}x^{2}=4.0 \\
x^{2}=11.1\end{array}$ & $\begin{array}{l}x^{2}=13.5^{*} \\
x^{2}=41.8^{* *}\end{array}$ & $\begin{array}{l}x^{2}=14.5^{*} \\
x^{2}=25.0^{*}\end{array}$ & $\begin{array}{l}x^{2}=16.2^{*} \\
x^{2}=24.4^{*}\end{array}$ & $\begin{array}{l}x^{2}=8.9 \\
x^{2}=23.1^{*}\end{array}$ & $\begin{array}{l}x^{2}=9.9 \\
x^{2}=41.6^{*}\end{array}$ \\
\hline
\end{tabular}


possible COVID-19 symptoms [19]. This study also reported that feeling better was another reason for not self-isolating, which was similar to our results.

Study strengths include a respectable sample size. While the sample size was adequate for our purposes and was diverse in terms of race/ethnicity, it does not necessarily represent the entire population of Louisiana and Mississippi. Compared to 2019 US Census data for the states of Louisiana and Mississippi [22, 23], our sample had approximately $24 \%$ more women, $11 \%$ less individuals with only a high school education, $17 \%$ more American Indian/Alaskan Natives, and 16\% less Whites. The electronic survey was an ideal data collection method amidst a pandemic and our approach leveraged widely used social platforms. However, bias may be introduced due to social media use and internet access required of our approach. Other limitations include biases associated with self-report measures. We also do not know the frequency of the social behaviors exhibited during the stay-at-home order, which could influence results.

\section{Conclusions}

As the US continues to manage the pandemic and identifies strategies to mitigate the transmission of COVID19, cultural and contextual factors need to be considered to identify state level strategies for most effective NPI implementation. As future stay-at-home/lockdown recommendations are considered by policy makers, understanding how social values, life stage, socioeconomic, and geographic factors influence stay-at-home order adherence would lead to more effective policy design to improve population adherence.

\section{Acknowledgements}

We would like to acknowledge other grant staff, intervention participants, outreach scholars, and community partners for facilitating this research.

\section{Authors' contributions}

$J L$ were informed the design of the study and provided study oversight as well as was a major contributor in forming the manuscript. TG implemented the statistical analyses and was a major contributor in forming the manuscript. SA facilitated data collection and development of manuscript components. LA, DW, JG, and ME provided external review of the study and were major contributor in informing the manuscript. All authors read and approved the final manuscript.

\section{Funding}

Research reported in this publication was supported by the Mississippi INBRE, funded by an Institutional Development Award (IDeA) from the National Institute of General Medical Sciences of the NIH under grant \# P20GM103476. The content is solely the responsibility of the authors and does not necessarily represent the official views of the National Institutes of Health.

\section{Availability of data and materials}

The datasets used and/or analyzed during the current study are available from the corresponding author on reasonable request.

\section{Declarations}

Ethics approval and consent to participate

All study protocol and materials were approved by The University of Southern Mississippi Institutional Review Board. Informed consent was obtained from all study participants. All methods were carried out in accordance with the described relevant guidelines and regulations. The USM IRB complies with federal regulations, including Federal Policy for the Protection of Human Subjects and operates under a Federal wide Assurance (FWA) on file with the Office for Human Research Protection (OHRP, Registration number: FWA00002393) in the U.S. Department of Health and Human Services. Human subjects research conducted at or supported by the University honors the three ethical principles enshrined in the "Belmont Report": respect for persons, beneficence, and justice. These general principles require that human research subjects, a) will not participate in research unless and until they have given voluntary and informed consent, b) persons under the age of 18 , legal incompetents, and those unable to consent may participate in research only with consent from a parent or legal guardian and, when possible, their assent, c) confidential information received from participants will be fully protected within the limits of the law, both during and after research is conducted, d) subjects may withdraw their participation at any time without penalty or loss of benefits to which they would otherwise be entitled, e) burdens put on research participants must be reasonable relative to anticipated benefits to themselves and to society as a whole, $f$ ) the selection of research participants must be equitable and defensible in terms of both the goals of the research and general considerations of fairness.

\section{Consent for publication}

Not applicable.

\section{Competing interests}

Authors report no competing interests.

\section{Author details}

${ }^{1}$ Mississippi INBRE Telenutrition Center, The University of Southern Mississippi, Hattiesburg, MS, USA. ${ }^{2}$ School of Kinesiology and Nutrition, The University of Southern Mississippi, 118 College Drive \#5142, Hattiesburg, MS 39406, USA. ${ }^{3}$ Mississippi INBRE Community Engagement and Training Core, Hattiesburg, MS, USA. ${ }^{4}$ School of Psychology and Center for American Indian Research and Studies, The University of Southern Mississippi, Hattiesburg, MS, USA. ${ }^{5}$ College of Nursing, The Florida State University, Tallahassee, Florida, USA. ${ }^{6}$ My Brother's Keeper, Inc., Jackson, MS, USA. ${ }^{7}$ Center for Molecular and Cellular Biosciences, Mississippi INBRE, The University of Southern Mississippi, Hattiesburg, MS, USA.

Received: 24 March 2021 Accepted: 19 October 2021

Published online: 23 November 2021

References

1. Trends in Number of COVID-19 Cases in the US Reported to CDC, by State/ Territory. Atlanta, GA: Centers for Disease Control and Prevention. https:// covid.cdc.gov/covid-data-tracker. Accessed Oct 30, 2020.

2. Price-Haywood EG, Burton J, Fort D, Seoane L. Hospitalization and mortality among Black patients and white patients with COVID-19. N Engl J Med. 2020;382(26):2534-43. https://doi.org/10.1056/NEJMsa2011686.

3. Gold JAW, Wong KK, Szablewski CM, et al. Characteristics and Clinical Outcomes of Adult Patients Hospitalized with COVID-19 - Georgia, March 2020. MMWR Morb Mortal Wkly Rep. 2020;69(18):545-550. Published 2020 May 8. doi:https://doi.org/10.15585/mmwr.mm6918e1

4. Masters NB, Shih SF, Bukoff A, et al. Social distancing in response to the novel coronavirus (COVID-19) in the United States. PLoS One. 2020;15(9): e0239025. Published 2020 Sep 11. doi:https://doi.org/10.1371/journal.pone. 0239025

5. COVID-19 Dashboard by the Center for Systems Science and Engineering. Johns Hopkins University website. https://coronavirus.jhu.edu/map.html. Accessed Oct 30, 2020.

6. Daigle A. Coronavirus cases grew faster in Louisiana than anywhere else in the world: UL study. TheAcadiana. https:/www.theadvocate.com/acadiana/ news/coronavirus/article_94494420-6d4b-11 ea-ac42-ff7dd722c084.html. . 
7. Hensley E. Mississippi COVID-19 hospitalization rate ranks second in nation amid state data blackout. Mississippi Today. https://mississippitoday.org/202 0/06/22/mississippi-covid-19-hospitalization-rate-ranks-second-in-nation-a mid-state-data-blackout/. .

8. Implementation of mitigation strategies for communities with local COVID19 transmission. Atlanta, GA: CDC. https://www.cdc.gov/coronavirus/2019ncov/community/community-mitigation.html. Accessed Oct 30, 2020.

9. Haug N, Geyrhofer L, Londei A, Dervic E, Desvars-Larrive A, Loreto V, et al. Ranking the effectiveness of worldwide COVID-19 government interventions. Nat Hum Behav. 2020;4(12):1303-12. https://doi.org/10.1038/ s41562-020-01009-0.

10. Community NPIs: Flu prevention in community settings. Atlanta, GA: CDC https:/www.cdc.gov/nonpharmaceutical-interventions/community/index.html.

11. CDC COVID-19 Community Survey Question Bank. Bethesda, MD: National Library of Medicine, NIH. https://cde.nIm.nih.gov/formView?tinyld=Kcceysolt. Published 2020. Accessed Oct 30, 2020.

12. Gao S, Rao J, Kang Y, Liang Y, Kruse J, Dopfer D, et al. Association of mobile phone location data indications of travel and stay-at-home mandates with COVID-19 infection rates in the US. JAMA Netw Open. 2020;3(9):e2020485. https://doi.org/10.1001/jamanetworkopen.2020.20485.

13. Hamidi S, Zandiatashbar A. Compact development and adherence to stayat-home order during the COVID-19 pandemic: a longitudinal investigation in the United States. Landsc Urban Plan. 2021;205:103952. https://doi.org/1 0.1016/j.landurbplan.2020.103952.

14. Williams SN, Armitage CJ, Tampe T, Dienes K. Public perceptions and experiences of social distancing and social isolation during the COVID-19 pandemic: a UK-based focus group study. BMJ Open. 2020;10(7):e039334. doi: https://doi.org/10.1136/bmjopen-2020-039334. Published 2020 Jul 20. doi:https://doi.org/10.1136/bmjopen-2020-039334

15. Hamadani JD, Hasan MI, Baldi AJ, Hossain SJ, Shiraji S, Bhuiyan MSA, et al. Immediate impact of stay-at-home orders to control COVID-19 transmission on socioeconomic conditions, food insecurity, mental health, and intimate partner violence in Bangladeshi women and their families: an interrupted time series. Lancet Glob Health. 2020;8(11):e1380-9 https://doi.org/10.1016/ S2214-109X(20)30366-1.

16. Attendance at religious services by state. Pew Research Center website. https://www.pewforum.org/religious-landscape-study/compare/attenda nce-at-religious-services/by/state/. Accessed Nov 11, 2020.

17. Clipman SJ, Wesolowski AP, Gibson DG, Agarwal S, Lambrou AS, Kirk GD, et al. Rapid real-time tracking of non-pharmaceutical interventions and their association SARS-CoV-2 positivity: The COVID-19 Pandemic Pulse Study [published online ahead of print, 2020 Sep 2]. Clin Infect Dis. 2020, 2021: ciaa1313. https://doi.org/10.1093/cid/ciaa1313.

18. Boehmer TK, DeVies J, Caruso E, van Santen KL, Tang S, Black CL, et al. Changing age distribution of the COVID-19 pandemic - United States, MayAugust 2020. MMWR Morb Mortal Wkly Rep. 2020;69(39):1404-1409. Published 2020 Oct 2. doi:https://doi.org/10.15585/mmwr.mm6939e1

19. Smith LE, Potts HW, Aml t R, Fear NT, Michie S, Rubin GJ. Adherence to the test, trace and isolate system: results from a time series of 21 nationally representative surveys in the UK (the COVID-19 Rapid Survey of Adherence to Interventions and Responses [CORSAIR] study). medRxiv. Published online September 18, 2020:2020.09.15.20191957. doi:https://doi.org/10.1101/2020. 09.15 .20191957

20. Fisher KA, Tenforde MW, Feldstein LR, Lindsell CJ, Shapiro NI, Files DC, et al. Community and close contact exposures associated with COVID-19 among symptomatic adults $\geq 18$ years in 11 outpatient health care facilities - United States, July 2020. MMWR Morb Mortal Wkly Rep. 2020;69(36):1258-1264. Published 2020 Sep 11. doi: https://doi.org/10.15585/mmwr.mm6936a5.

21. Czeisler MÉ, Tynan MA, Howard ME, Honeycutt S, Fulmer EB, Kidder DP, et al. Public Attitudes, behaviors, and beliefs related to COVID-19, stay-athome orders, nonessential business closures, and public health guidance United States, New York City, and Los Angeles, May 5-12, 2020. MMWR Morb Mortal Wkly Rep. 2020;69(24):751-758. Published 2020 Jun 19. doi: https://doi.org/10.15585/mmwr.mm6924e1

22. U.S. Census Bureau QuickFacts: Louisiana. Accessed May 27, 2021. https:// www.census.gov/quickfacts/LA

23. U.S. Census Bureau QuickFacts: Mississippi. Accessed May 27, 2021. https:// www.census.gov/quickfacts/MS

\section{Publisher's Note}

Springer Nature remains neutral with regard to jurisdictional claims in published maps and institutional affiliations. 